\title{
Proportionality and the Right to Equality
}

\author{
Guy Lurie*
}

(Received 15 February 2019; accepted 19 June 2019)

\begin{abstract}
This Article focuses on the overlap and interaction between the doctrine of proportionality and the doctrines used to assess the constitutionality of state violations of the right to equality. The Article has three main contributions to comparative constitutional literature. First, the Article pinpoints the difficulty that arises when courts try to apply the doctrine of proportionality on claimed violations of the right to equality. Analytically, as shown in this Article, the overlap and interaction between these two doctrines is problematic because they are both relational measures between means and ends. Second, this Article categorizes two models adopted by courts in the application of proportionality in the context of the violation of the right to equality. Third, this Article points out that the choice of the model used by each court is relevant to the ongoing discourse on the advantages and disadvantages of proportionality.
\end{abstract}

Keywords: Proportionality; right to equality; judicial review; Canada; the European Court of Human Rights; Germany; Israel; South Africa

\section{A. Introduction}

This Article focuses on the overlap and interaction between the doctrine of proportionality and the doctrines used to assess the constitutionality of state violations of the right to equality. Proportionality is a doctrine that an increasing number of courts are using to determine the constitutionality of the limitations of rights. Generally, this doctrine calls for the examination of all rights in a similar "one size fits all" manner. This Article examines this doctrinal contention through focusing on how the courts of Canada, Germany, Israel, and South Africa, as well as the European Court of Human Rights ("ECtHR") apply proportionality with regard to claimed violations of the right to equality.

The Article has three main contributions to comparative constitutional literature. First, the Article shows that all the courts examined herein face the same pathology in trying to apply the doctrine of proportionality on claimed violations of the right to equality. These two doctrines are relational normative measures between the ends and the means of state policies. Both doctrines balance interests, values, and rights. Analytically, as shown in this Article, their overlap and interaction are thus problematic.

Second, this Article surveys two models that courts use in applying proportionality in the context of the violation of the right to equality: (1) A doctrine or practice of constitutional review

${ }^{\star}$ Israel Democracy Institute and a visiting scholar at the Department of History at Cornell University. Email: guyl3@idi.org.il. The research for this Article was supported by the "Proportionality in Public Policy" research project at the Israel Democracy Institute, funded by the European Research Council under the European Union's Seventh Framework Programme (FP7/20072013)/ERC Grant No 324182. I would like to thank Mordechai Kremnitzer, Talya Steiner, and an anonymous reviewer for comments on drafts.

(c) The Author(s) 2020. Published by Cambridge University Press on behalf of the German Law Journal. This is an Open Access article, distributed under the terms of the Creative Commons Attribution-NonCommercial licence (http://creativecommons.org/licenses/by-nc/4.0/), which permits unrestricted re-use, distribution, and reproduction in any medium, provided the original work is properly cited 
focusing on the scope of the right and its infringement; and (2) inconsistency in the application of the doctrine or a sliding scale.

Third, this Article points out that the choice of the model used by each court is relevant to the ongoing discourse on the advantages and disadvantages of the use of proportionality. Some of the criticisms directed toward the doctrine of proportionality are exactly its "one size fits all" treatment of all rights and its inherent perception of all rights as principles susceptible to optimization. On the one hand, the findings of this Article suggest that some of these criticisms have merit because of the exceptional problematic application of proportionality in the context of the right to equality. Namely, in the first model, the right to equality is treated as a categorical prohibition in a singlestep constitutional review rather than a principle optimized according to the standard twostep proportionality doctrine. Thus, the proportionality doctrine is not so easily applied consistently and universally. On the other hand, the existence of the two models identified in this Article also show that it is possible nonetheless to accommodate the doctrine of proportionality with the substantive definitions of the right to equality. Indeed, the usage of tests akin to proportionality in the substantive definition of the right to equality, as detailed below, perhaps hints at the inherent value of the subtests of proportionality.

Section B surveys discussions on the proportionality doctrine. Section C shows analytically why the tests used to examine the constitutionality of claimed violations of the right to equality interact poorly with the proportionality doctrine. Section D surveys and analyzes five comparative examples of this problematic interaction between the doctrines, detailing the two models used by jurisdictions: (1) Focusing on the scope of the right and its infringement; or (2) a sliding scale. Section E discusses the implications of the findings and of the choice of models. The last Section concludes and summarizes the Article.

\section{B. Proportionality}

The use of proportionality in judicial review is hotly debated in academic discourse. As proportionality spreads to more and more jurisdictions and is being utilized by more and more courts who perceive that it is "essential to the performance of their duties," its usage also becomes more and more contested, partly because of the expansion it entails to judicial authority. ${ }^{1}$ In constitutional contexts, proportionality refers to a set of standards used to decide upon the constitutionality of an infringement on constitutionally protected rights. Proportionality generally involves a twostage review. First, the court examines whether the state action in question infringes, interferes with, or limits a constitutionally protected right. Such an examination involves determining what the scope of the right is. Second, the court examines whether the state action in question limits the right in a way justifiable through the subtests of the doctrine of proportionality. Of course, there is some variation on the exact content of these tests. The first two preliminary requirements are that the action is: (1) According to law or prescribed by law; and (2) for a proper or legitimate purpose. The three subtests of proportionality itself then follow. These require that the state action is: (1) With a rational connection between the means and the ends; (2) the means are necessary without an alternative measure that may achieve the same end with a less onerous limitation of the right; and (3) a balancing of the benefits to the purpose of the measure and the detriments of the limitation of the right. ${ }^{2}$

Some scholars hail proportionality as no less than the new "ultimate rule of law."3 According to proponents of proportionality, courts should use this legal tool in reviewing infringements of human rights, because it is the best indispensable analytical tool to ensure the protection of human

\footnotetext{
${ }^{1}$ Alec Stone Sweet \& Jud Mathews, Proportionality Balancing and Global Constitutionalism, 47 ColUm. J. TranSNAT'L L. 72 , 160-61 (2008). For more on the spread of proportionality, see AHARon BARAK, Proportionality: Constitutional Rights AND their Limitations 175-210 (2012); Moshe Cohen-Eliya \& Iddo Porat, American Balancing and German Proportionality: The Historical Origins, 8 InT'L J. CONST. L. 263 (2010).

${ }^{2}$ See BARAK, supra note 1.

${ }^{3}$ David M. Beatty, The Ultimate Rule of Law (2004).
} 
rights in a just, rational, and systematic manner. ${ }^{4}$ Opponents of the use of proportionality as a legal tool in such contexts see it as a detriment to human rights. According to such scholars, proportionality is too universally applied, even though it is not always appropriate for all rights. It also inhibits legal certainty, because of its focus on the circumstances of each particular case to determine the result of the judicial review. Furthermore, they argue, the use of proportionality vainly and wrongly attempts to depoliticize constitutional rights, it is incommensurable in comparing values that could not be measured and balanced, and it does violence to the very idea of human rights and the constitution. ${ }^{5}$

The debate on proportionality is related to another debate regarding the nature of rights themselves and the question: What are rights? Are all rights the same? Are at least some rights based on deontological rules of morality-for example, it is strictly forbidden to torture someone, no matter what - or are they all utilitarian principles, and thus relate to the overall public utility-for example, freedom of expression should be balanced with public safety? This difference is derived from the analytical opposition of rights versus principles. On the one hand, principles—or standardsare either applicable or not, but they may not derive a specific outcome. They need to be weighed according to the circumstances of the case and optimized accordingly. ${ }^{6}$ Rules, on the other hand, have a direct consequence. They may have exceptions or conflicting rules, yet they act differently than principles. ${ }^{7}$ If rights are utilitarian principles, balancing rights and public interests is appropriate-arguably, through proportionality. ${ }^{8}$ Yet, according to many critics, rights are not primarily-or, according to some critics, not only-principles that could be optimized and balanced with various public interests. If rights are deontological moral rules, any infringement due to any public interest is not allowed. According to this understanding of rights, they should act as firewalls against other considerations and trump contending public interests. They are absolute or have a core that should be absolutely protected. ${ }^{9}$

Returning to the opposing views on the usage of proportionality, the opponents ultimately see proportionality in similar - though not identical—analytical terms. Generally speaking, scholars view proportionality as an analytical tool or a criterion used for the optimization of principles. The issue of its appropriateness depends, at least analytically, on the view of the nature of rights, if we ignore, for the moment, other previously mentioned criticisms aimed at proportionality, such as the doctrine's incommensurability, vain depoliticization of human rights, or rising judicial power. In purely analytical terms, the view one has on the nature of human rights, as a continuum between pure rules and pure principles, influences the view one would have on the appropriateness of the usage of proportionality. Either way, the balancing of principles is more appropriate than the balancing of rules.

\footnotetext{
${ }^{4}$ Niels Petersen, Proportionality and Judicial Activism: Fundamental Rights Adjudication in Canada, GERMANY AND SOUTH AFrica 53-69 (2017); BARAK, supra note 1; Kai Möller, Proportionality: Challenging the Critics, 10 InT'L J. Const. L. 709 (2012); Matthias Katt \& Moritz Meister, Proportionality-A Benefit to Human Rights? Remarks on the I·CON Controversy, 10 InT'L J. Const. L. 687 (2012); Aharon Barak, Proportionality and Principled Balancing, LAw \& Ethics Hum. RTs., Jan. 2010, at 1; Mattias Kumm, The Idea of Socratic Contestation and the Right to Justification: The Point of Rights-Based Proportionality Review, LAw \& ETHICs HuM. RTS., Jan. 2010, at 141; BEATTY, supra note 3; RoBERT Alexy, A Theory of Constitutional Rights 66-69 (2002).

${ }^{5}$ Ariel L. Bendor \& Tal Sela, How Proportional Is Proportionality? 13 InT'L J. ConsT. L. 530 (2015); Grégoire C. N. Webber, Proportionality, Balancing, and the Cult of Constitutional Rights Scholarship, 23 CAN. J. L. \& JURIS. 179 (2010); Stavros Tsakyrakis, Proportionality: An Assault on Human Rights?, 7 InT'L J. Const. L. 468 (2009); Vicki C. Jackson, Being Proportional About Proportionality, 21 Const. Comment. 803 (2004).

${ }^{6}$ See, e.g., AleXY, supra note 4, at 66.

${ }^{7}$ ALEXY, supra note 4, at 66.

${ }^{8}$ Matthias Klatt, An Egalitarian Defense of Proportionality-Based Balancing: A Reply to Luc B. Tremblay, 12 INT'L J. ConsT. L. 861 (2014); BARAK, supra note 1; Mattias Kumm, Constitutional Rights as Principles: On the Structure and Domain of Constitutional Justice, 2 InT'L J. Const. L. 574 (2004); AleXy, supra note 4, at 66.

${ }^{9}$ Kai Möller, Balancing and the Structure of Constitutional Rights, 5 INT'L J. Const. L. 453 (2007); RONALD DWORKIN, TAKING Rights SERIOUSLY 92 (1977).
} 
Proponents of the proportionality doctrine premise it on a clear definition of the scope of rights and on its appropriateness as a standard analytical tool. Critics of the use of proportionality argue that its use trivializes a clear definition of the scope of individual rights. ${ }^{10}$ Without accepting or negating such criticism, two related premises of the doctrine of proportionality are important in our context. The first premise of the doctrine is that one should be able to clearly define each right in the first stage of the judicial review, when the judge determines if an action has infringed or interfered with that right. Otherwise, the second stage of reviewing the justification of the infringement is not possible. The second premise to emphasize in the doctrine of proportionality is its "one size fits all" nature. The result of the judicial review varies according to the circumstances of the cases, yet the content of the tests themselves is more or less constant. These two premises are, of course, based on a somewhat simplified view of the doctrine of proportionality, while the actual doctrinal application varies and is more complex. ${ }^{11}$ These premises are nevertheless part of the idealized doctrine of proportionality.

What happens when the right in question is not so easily defined? What happens when standard definitions make the subtests of proportionality redundant? We now turn to these questions, with regard to the right to equality, or non-discrimination.

\section{The Right to Equality}

The right to equality evades clear definitions perhaps more so than other rights. Usually, the right to equality signifies a right to a certain type of treatment in comparison to others. ${ }^{12}$ As such, the right to equality is more difficult to define than other rights, such as the right to life, liberty, or freedom of speech. This is the case even for other rights that are also claims - in the Hohfeldian system of analysis - such as a right to minimum wage, which are not comparative like the right to equality.

When we say that there should be equality between two or more people, we still beg the question: Equality in what sense? When Aristotle defined distributive justice according to the principle of equal treatment_ "treating like cases as like"13 — his underlying premise was that people are essentially different. According to Aristotle, it was just to give unequal treatment to people of different natures. Men and women, slaves and free people, and citizens and noncitizens all deserved different treatment based on their different natures. While political justice, according to Aristotle, exists between equal citizens, not everyone in the best polity are citizens, excluding slaves, women, and vulgar persons (banausos) and laborers (thess) who perform necessary work. ${ }^{14}$

The modern conception is different. Through the end of medieval times for Aristotle and other writers, the reigning conception was that people had different natures and were thus unequal. The modern legal conception, as exemplified in Thomas Hobbes' Leviathan, is that "nature hath made men ... equal in the faculties of body and mind." ${ }^{15}$ Generalizing the modern conception of man as equal is, of course, simplistic. One can readily see this in modern racist discourse-justifying, for instance, the enslavement of other "races" or, in modern justifications, for not granting women equal rights of citizenship. Immanuel Kant, for instance, held a conception of the "complete equality of men as subjects in a nation," due to their natural capacity to use reason and will to act according to a selfimposed duty: Moral or political. Yet, at the same time, Kant distinguished between men who were completely rational and other people in society who were not completely rational, such as women, who were thus unable to act through only selfimposed moral or political duties. ${ }^{16}$

\footnotetext{
${ }^{10}$ See Bendor \& Sela, supra note 5; Tsakyrakis, supra note 5.

${ }^{11}$ On the varied application of the doctrine of proportionality, see PETERSEN, supra note 4; BARAK, supra note 1.

${ }^{12}$ Stefan Gosepath, Equality, in STANFORD ENCYCLOPEDIA OF PHILOSOPHY (2011), available at http://plato.stanford.edu/ archives/spr2011/entries/equality/.

${ }^{13}$ Aristotle, Nicomachean Ethics, in The Basic Works of Aristotle 1006 (Richard McKeon ed., 1941).

${ }^{14}$ Aristotle, Politics 93 (Carnes Lord trans., 1984).

${ }^{15}$ Thomas Hobbes, Leviathan 74 (Edwin Curley ed., 1994).

${ }^{16}$ Immanuel Kant, Theory and Practice, in Perpetual Peace and Other Essays on Politics, History, and Morals 73,76 (Ted Humphrey trans., 1983).
} 
Notwithstanding the limitations of this generalization, the presumption of the equal nature of all humans complicates the Aristotelian formula of equal treatment as "treat like cases as like." Each person is unique in his or her physical, mental, and other traits, such as color of hair, manner of speech, and preferences in music. No person is exactly the same as another. In contrast, because we assume as a matter of law that all human beings share the same nature and thus deserve the same legal treatment, what kind of different cases deserve different treatment? While, for Aristotle, the difference in nature between types of persons was selfevident-men versus women, free people versus slaves - we have more trouble discerning "relevant differences." Thus, the Aristotelian formula, which was relatively simple in an ancient conception of the normatively different natures and legal statuses of men, has become extremely complicated in a modern conception of the normatively equal nature of man. This problem has produced a lot of discussion in political philosophy on the issue that has been called the "Equality of What?" debate: Equal rights, equal opportunities, or the capabilities approach, among others. ${ }^{17}$

The "empty" character of the right to equality has also been widely recognized in law. In legal doctrines of constitutions and courts, as well as in legal theories of writers, this problem has produced a wideranging difficult search for a substantive definition of the right to equality. Putting aside the more general right to equality, even the more specific right to non-discrimination has remained problematic. Problems remain even when constitutions specify a lengthy rule, as opposed to a principle, prohibiting discrimination. The question that courts and writers ask is generally summed up as: "[W]hich differential treatment amounts to discrimination?"18

Constitutions and courts have found various solutions to imbuing substance to the right to equality, or, more accurately, to the rule of non-discrimination, through various tests examining when differential treatment amounts to discrimination. Yet these solutions are problematic in terms of using them in the regular twostep constitutional review, according to the doctrine of proportionality. One solution is specifying suspect grounds for differentiation, such as race, ethnicity, or sex, and then examining their justifications, often through proportionality tests. ${ }^{19}$ Yet there is something uniquely rulelike and deontological in a prohibition against discrimination on such suspect grounds. Even if courts try to analyze such cases as if such a prohibition is a "principle of non-discrimination" to be optimized through proportionality analysis, it acts more like a rule rather than a principle. Thus courts tend to use proportionality not as an analytical tool to optimize principles but rather as a way to define the right to equality and ascertain its scope, seeking to see if the rule prohibiting discrimination applies in a given case. In other words, the prohibition against discrimination on suspect grounds, or groups, acts not as a balancing of principles but rather as a categorical prohibition — an absolute right, such as the right against tortureor as a core of a right that cannot be infringed. If we deem the right to have been infringed, we will disallow the act of infringement. If not infringed, it will be allowed. There will be no area of allowed infringement due to a balancing with other rights or interests. Thus, even if proportionality is applied to non-discrimination, courts tend to analyze it as a rule: Has the rule been infringed? And if so, is it illegal?

Other cases in which suspect grounds are not involved are actually even more problematic. In such cases, because we lack a strictly clear categorical definition of the right in question-in this

\footnotetext{
${ }^{17}$ For a survey of this debate, see Ian Carter, Respect and the Basis of Equality, 121 ETHICS 538, 542 (2011). Some of the important contributions to this debate include: Martha C. Nussbaum, Creating Capabilities: The Human Development ApProach (2011); Amartya Sen, InEQuality REeXAmined (1992); Richard J. Arneson, Equality and Equality of Opportunity for Welfare, 56 PHIL. STUD. 77 (1988).

${ }^{18}$ See Sandra Fredman, Substantive Equality Revisited, 14 InT'L J. Const. L. 712 (2016); Rory O'Connell, The Role of Dignity in Equality Law: Lessons from Canada and South Africa, 6 InT'L J. Const. L. 267 (2001); Peter Westen, The Empty Idea of Equality, 95 HARv. L. Rev. 537, 545, 547 (1982).

${ }^{19}$ As David Beatty notes, despite a wide disparity of language in the way that the right to equality is phrased in constitutions, courts mostly apply proportionality analysis in assessing its infringement in matters of discrimination against women. See BEATTY, supra note 3, at 80-81. See also infra Section D (discussing the examples of Canada and the ECtHR).
} 
case, the right to equality - any solution that involves relational measures to define the right would make the uses of the tests of proportionality redundant or cumbersome. Such a definition of the right to equality would be cumbersome because it involves using one relational optimization measure-is a given differential treatment discrimination in certain circumstances-after another-is this discrimination justified in these circumstances according to the doctrine of proportionality. Such definitions of the right to equality make proportionality redundant, because when trying to imbue some substantive quality to the right to equality, jurisdictions often resort to tests that sound very close to proportionality. Some jurisdictions simply import the whole proportionality test into the definition of equality. ${ }^{20}$ In other cases, a test of infringement of human dignity is imported into the right to equality. The conceptual manner in which an infringement of human dignity also becomes an infringement of the right to equality depends on the court's conception of human dignity. At times, this is varied or not clearly explained. Such an infringement may occur, for instance, through humiliation by treatment of individuals as inferior, through discrimination that disregards a person's autonomy and free will, or through unequal distribution of social goods, which fails to recognize the equal intrinsic value of all human beings. ${ }^{21}$ In any case, such an infringement of human dignity may become such an onerous test that it makes proportionality redundant. If the right to equality is qualified by the right to human dignity-for instance, in the sense that an infringement of the right to equality is such that the ground for differentiation has "the potential to impair the fundamental human dignity of persons as human beings" - what type of discrimination could be justified in such a case? ${ }^{22}$

Even if we resort to the formal Aristotelian test for discrimination, it becomes redundant when used to define the right to equality for the purposes of the proportionality doctrine. The reason for the redundancy is that the formal Aristotelian "relevant difference" formula is a relational meansends test or measure, much like proportionality. The similarity becomes apparent if we look at the subtests of proportionality. At least the first two are the same as the first two tests of the classic formal Aristotelian non-discrimination formula: Rational relation between meansends and necessity of the means used, for proportionality, and relevant distinction, for discrimination. Indeed, both the general principle of proportionality and the Aristotelian formula have a common origin in Aristotle's perception of distributive justice as a proportionate ratio between two people-or between the ends and the means. ${ }^{23}$ It is thus at least partly redundant to examine through the proportionality doctrine a violation of the right to equality or non-discrimination in its formal Aristotelian definition. How can we examine whether there is an illegitimate disproportion in the distribution of something between two groups of people, through a test which only shows the existence of such a disproportion? If the first stage of the test-the Aristotelian formulahas already shown us that there is a disproportion between two groups of people, then there is little use for a second stage looking to examine justifications for this disproportion, through another test of disproportion. Returning to the attempts to give substance to non-discrimination, some of the moral bases for the wrongfulness of discrimination describe it as a mistake in moral or rational deliberation and reasoning. Discrimination is wrongful, in this description, because it takes account of "irrational," "irrelevant," or "morally insignificant" facts. ${ }^{24}$ In other words, we again recognize discrimination, in this account, through a meansends test not unlike proportionality.

In order to demonstrate these problems of the relationship between the definition of the right to equality and the proportionality doctrine, this Article will now turn to a comparative examination of the ways that some jurisdictions do so.

\footnotetext{
${ }^{20}$ See infra Section D (discussing the ECtHR).

${ }^{21}$ O'Connell, supra note 18; Tamar Hostovsky Brandes, Human Dignity as a Central Pillar in Constitutional Rights Jurisprudence in Israel: Definitions and Parameters, in IsRaeli Constitutional LaW In the MaKing (Gideon Sapir et al. eds., 2013). See infra Sections D.I.1, I.2, II.2.

${ }^{22}$ See infra Section D.I.2 (discussing South Africa).

${ }^{23}$ See, e.g., Eric Engle, The History of the General Principle of Proportionality: An Overview, 10 DARTMOUTH L.J. 1 (2012).

${ }^{24}$ Re'em Segev, Making Sense of Discrimination, 27 RATIO JuRIS 47, 62-67 (2014).
} 


\section{A Comparative Study}

The comparative study below focuses on five jurisdictions: Canada, the European Court of Human Rights ("ECtHR"), Germany, Israel, and South Africa. In each jurisdiction, the examination is on the doctrine of proportionality and its specific application with regards to the right to equality. Textual examples are also analyzed to show the problematics of applying these two doctrines in tandem.

As shown below, the five jurisdictions examined herein are divided into two distinct models of accommodating the doctrine of proportionality and the right to equality. In the first model, the doctrine or practice of constitutional review focuses on the scope of the right and its infringement, either doctrinally - in the case of the ECtHR — or in practice - in the cases of Canada and South Africa-through simply almost never accepting, in the second stage of proportionality, a justification of an infringement of the right to equality. In the second model, the doctrine-with regard to the application of proportionality with the right to equality-is either explicitly inconsistent, supporting a sliding scale - as in the case of Germany-or implicitly inconsistent in the practice of the courts, as in the case of Israel.

\section{Focus on the Definition of the Right to Equality}

First, let us examine the ways that Canada, South Africa, and the ECtHR apply proportionality in the context of the right to equality. As shown below, these three jurisdictions apply the first model, wherein the doctrine or practice of constitutional review focuses on the scope of the right and its infringement. In the case of the ECtHR, this model is manifest in the doctrine of proportionality itself and its different applications rather than in other rights. In the cases of Canada and South Africa, the model is manifest in the practice of the courts, in which they almost never accept, in the second stage of proportionality, a justification of an infringement of the right to equality.

In all three cases, courts practice constitutional review differently in the context of the right to equality than in the context of other rights. In this model, courts discard the twostep constitutional review: First, defining the scope of the right and its infringement and then analyzing the justifications for this infringement. Rather, in this model, courts apply a singlestep constitutional review, focused on defining the scope of the right and its infringement. In such a model, the prohibition against discrimination acts more like a categorical prohibition-a deontological rule rather than a principle. As explained in Section C, the courts do so because of the problematic analytical relationship between the right to equality and proportionality. I will illustrate this phenomenon through particular cases elaborated upon in this Section.

\section{Canada}

The Canadian Charter of Rights and Freedoms ("Charter") protects the right to equality in Section 15:

(1) Every individual is equal before and under the law and has the right to the equal protection and equal benefit of the law without discrimination and, in particular, without discrimination based on race, national or ethnic origin, colour, religion, sex, age or mental or physical disability.

Section 1 of the Charter sets out the justifiable limitations of this right:

The Canadian Charter of Rights and Freedoms guarantees the rights and freedoms set out in it subject only to such reasonable limits prescribed by law as can be demonstrably justified in a free and democratic society.

Section 1 thus prescribes a proportionality test for the purposes of determining if a challenged law, which has been determined as limiting the right to equality according to Section 15, is justified. 
Initially, the Supreme Court of Canada explicitly sought to retain roles for both Section 15 and Section 1. The first stage involved an examination of whether distinctions are made according to the grounds "enumerated" in Section 15 or analogous grounds and an examination of their effect; the second stage involved examining the justification of this discrimination according to Section 1:

Where discrimination is found a breach of s. 15(1) has occurred ... any justification, any consideration of the reasonableness of the enactment; indeed, any consideration of the factors which could justify the discrimination and support the constitutionality of the impugned enactment would take place under s. $1 .^{25}$

As formerly determined by the Supreme Court of Canada before 1999, the starting point of justifying such a limitation is "an assessment of the objectives of the law to determine whether they are sufficiently important to warrant the limitation," followed by "a proportionality test in which the objective of the impugned law is balanced against the nature of the right, the extent of its infringement and the degree to which the limitation further other right or policies of importance." 26 This proportionality test includes three aspects: (1) Rational connection to the objective; (2) as little as possible impairment of the right; and (3) the effects must not so severely trench on rights that the objective is outweighed by the abridgement of rights. ${ }^{27}$

Despite the Charter's prescription of a proportionality test for the determination of whether a limitation on the right to equality is justified, in practice, the Supreme Court of Canada has not consistently done so. Since 1999, the Court has focused on the determination of violation of rights according to Section 15 and not on the proportionality test according to Section 1. This focus has been manifesting since 1999, when the Court added an additional element to proving violation of the right according to Section 15, besides showing legislative distinctions or differential impact based on a listed or analogous ground: Violation of the purpose of the Charter. This latter element, for the purposes of determining whether a violation has occurred, generally involves an examination of whether there has been an impairment of human dignity. More recently, this has been rephrased as an open list, including "some important contextual factors influencing the determination of whether Section 15(1) has been infringed":

(A) Pre-existing disadvantage, stereotyping, prejudice, or vulnerability experienced by the individual or group at issue ....

(B) The correspondence, or lack thereof, between the ground or grounds on which the claim is based and the actual need, capacity, or circumstances of the claimant or others ....

(C) The ameliorative purpose or effects of the impugned law upon a more disadvantaged person or group in society ... and

(D) The nature and scope of the interest affected by the impugned law. The more severe and localized the consequences of the legislation for the affected group, the more likely that the differential treatment responsible for these consequences is discriminatory $\ldots{ }^{28}$

These factors, introduced in the Court's landmark 1999 Law v. Canada case-in which the Court rejected a woman's appeal against the constitutionality of her denial of survivor's benefits under the Canadian Pension Plan based on her young age-are very reminiscent of proportionality analysis, making it somewhat redundant, as will be shown in more detail below. ${ }^{29}$

\footnotetext{
${ }^{25}$ Andrews v. Law Society of British Columbia, [1989] 1 S.C.R. 143, 182 (Can.).

${ }^{26}$ McKinney v. University of Guelph, [1990] 3 S.C.R. 229, 280 (Can.).

${ }^{27}$ R. v. Edwards Books \& Art Ltd., [1986] 2 S.C.R. 713, 768 (Can.).

${ }^{28}$ Law v. Canada, [1999] 1 S.C.R. 497, 550-51.

${ }^{29}$ See Peter Hogg, Constitutional Law of Canada 1201-02 (student ed. 2009), and the literature cited therein.
} 
Since 1999, in almost all cases, the Court seems to focus on the first stage of examining whether the right to equality has been infringed upon according to Section 15 and does not focus on Section 1 by justifying such infringements or limitations. In other words, when the Court applied the Charter, its determination of a violation of Section 15 was mostly followed by a decision that it was unjustified under Section 1. Once an infringement of the right to equality under Section 15 of the Charter has been shown, in practice, it is almost impossible to prove that it is a justifiable infringement under the proportionality test. ${ }^{30}$

In 2011, the Supreme Court of Canada slightly revised the test of determining whether a law limits the right to equality according to Section 15. It eliminated the "mirror comparator analysis" that was formerly part of the test, and focused on the "discrimination on suspect grounds" analysis. ${ }^{31}$ Since then, the Court has not found any case of a violation of Section 15 justified under Section 1.

Recent cases, since 2011, show the problematic nature of the factors considered for determining whether there has been a violation of the right to equality under Section 15, which make a proportionality analysis practically redundant. Take, for instance, a recent court decision-in which the Supreme Court of Canada decided that there was no violation of Section 15-in a case involving a chief of the Kahkewistahaw First Nation, who argued against the constitutionality of a new requirement of Grade 12 education in order to become a candidate for chief. In describing the type of test and factors used, the Court explained the stages of the analysis:

The focus of s. 15 is therefore on laws that draw discriminatory distinctions - that is, distinctions that have the effect of perpetuating arbitrary disadvantage based on an individual's membership in an enumerated or analogous group .... The first part of the s. 15 analysis therefore asks whether, on its face or in its impact, a law creates a distinction on the basis of an enumerated or analogous ground .... The second part of the analysis focuses on arbitrary - or discriminatory - disadvantage, that is, whether the impugned law fails to respond to the actual capacities and needs of the members of the group and instead imposes burdens or denies a benefit in a manner that has the effect of reinforcing, perpetuating or exacerbating their disadvantage. ${ }^{32}$

In describing these tests, the Court ascribed an analysis focused on the disproportionate effect of the law on the claimant in order to prove discrimination:

To establish a prima facie violation of s. 15(1), the claimant must therefore demonstrate that the law at issue has a disproportionate effect on the claimant based on his or her membership in an enumerated or analogous group .... The question in this case is which "enumerated or analogous group" faces discrimination, and whether Mr. Taypotat has established that the education requirement set out in the Kahkewistahaw Election Act has a disproportionate effect on the members of any such group. ${ }^{33}$

\footnotetext{
${ }^{30}$ See, e.g., Tétreault-Gadoury v. Canada (Canada Employment and Immigration Commission), [1991] 2 S.C.R. 22; Miron v. Trudel, [1995] 2 S.C.R. 418 (Can.). For similar analyses, see Vicki C. Jackson, Proportionality and Equality, in Proportionality: New Frontiers, New Challenges 171, 187 (Vicki C. Jackson \& Mark Tushnet eds., 2018); HoGg, supra note 29, at 1226; Mary C. Hurley, Charter Equality Rights: Interpretation of Section 15 in Supreme Court of Canada Decisions, in LaW And Government Division, Parliament of CANada (March 2007), available at http://epe.lac-bac.gc.ca/100/200/ 301/library_parliament/backgrounder/2007/charter_equality-e/bp402-1e.pdf; Richard Moon, Justified Limits on Free Expression: The Collapse of the General Approach to Limits on Charter Rights, 40 Osgoode HaLL L.J. 337, 365-66 (2002).

${ }^{31}$ Withler v. Canada (Attorney General), 2011 SCC 12, [2011] 1 S.C.R. 396.

${ }^{32}$ Kahkewistahaw First Nation v. Taypotat, 2015 SCC 30, [2015] 2 S.C.R. 548 (Can.).

${ }^{33} I d$.
} 
This type of analysis is so similar to the proportionality test that it is clear why it is difficult to use one after the other. Yet, it is this kind of proportionalitytype analysis, the disproportionately negative impact test, which the Court endorsed in its recent 2011 leading case on equality, Withler $v$. Canada (Attorney General). Withler involved widows who argued unsuccessfully against the constitutionality of the reducing of their federal supplementary death benefits because the age of their husbands at the time of death exceeded a prescribed age:

In some cases, identifying the distinction will be relatively straightforward, because a law will, on its face, make a distinction on the basis of an enumerated or analogous ground (direct discrimination). This will often occur in cases involving government benefits, as in Law, Lovelace and Hodge. In other cases, establishing the distinction will be more difficult, because what is alleged is indirect discrimination: that although the law purports to treat everyone the same, it has a disproportionately negative impact on a group or individual that can be identified by factors relating to enumerated or analogous grounds. ${ }^{34}$

In other words, the analysis used to examine a violation of the right to equality, according to Section 15 of the Charter, is itself based on a proportionalitytype analysis, making the proportionality analysis of Section 1 of the Charter redundant. It is not just the general relational-or proportionalanalysis used with regard to the right to equality that is similar to the proportionality test but also the specific subtests of proportionality that find resonance in the equality test that the Court endorses:

The analysis at the second step is an inquiry into whether the law works substantive inequality, by perpetuating disadvantage or prejudice, or by stereotyping in a way that does not correspond to actual characteristics or circumstances. ${ }^{35}$

This passage is practically identical to the rational relation subtest of proportionality, making it redundant. Such redundancy and similarity to the subtests of proportionality are also apparent in this "second step" of the Section 15 right of equality analysis:

[T] he contextual inquiry at the second step of the s. 15(1) analysis will typically focus on the purpose of the provision that is alleged to discriminate, viewed in the broader context of the scheme as a whole .... In determining whether the distinction perpetuates prejudice or stereotypes a particular group, the court will take into account the fact that such programs are designed to benefit a number of different groups and necessarily draw lines on factors like age. It will ask whether the lines drawn are generally appropriate, having regard to the circumstances of the persons impacted and the objects of the scheme. Perfect correspondence between a benefit program and the actual needs and circumstances of the claimant group is not required. Allocation of resources and particular policy goals that the legislature may be seeking to achieve may also be considered. ${ }^{36}$

To reiterate, all these subtests are very similar to the proportionality subtests, ${ }^{37}$ which helps to explain why, in recent years, the court has not found any case of a violation of Section 15 justified under Section 1.

In previous years, some exceptions to this empirical generalization have occurred. The court had then explicitly maintained an onerous proportionality test in equality cases:

\footnotetext{
${ }^{34}$ Withler v. Canada (Attorney General), 2011 SCC 12, [2011] 1 S.C.R. 396, para. 64.

${ }^{35} I d$. at para. 65.

${ }^{36} I d$. at para. 67.

${ }^{37}$ See also Quebec (Attorney General) v. A., 2013 SCC 5, [2013] 1 S.C.R. 61 (Can.).
} 
"[G]iven that s. 15 is designed to protect those groups who suffer social, political and legal disadvantage in our society, the burden resting on government to justify type of discrimination against such groups is appropriately an onerous one." ${ }^{38}$ Despite applying this onerous proportionality test, in some cases-such as a 1990 case of an application of professors against a mandatory retirement age-the Court ruled that an infringement of the equality right was justified according to the proportionality test. Yet, in these cases, the charter was either not applicable - to universities, in the aforementioned case $\mathrm{c}^{39}$ - or it was doubtful whether there was any violation of Section $15,{ }^{40}$ and so the issue was theoretical.

The analysis of the Court in these cases is revealing. For instance, in a case involving a claim of discrimination between heterosexual couples and homosexual couples-a homosexual person was denied spousal allowance under the Old Age Security Act because his homosexual partner of several decades was not perceived as his "spouse"-the Court ruled that for the purposes of that law-old age benefits - the distinction was relevant, because according to the Court, the idea was to help couples with the ability to procreate. Relevance was analyzed by the Court in that case through an examination of the connection between the measure of the distinction and its effect, and the purpose of the law. Thus, it was decided that no violation of the right to equality was found. And even if there were, continued the Court, it would have been justified under Section 1: "[F] or the considerations set forth in my reasons in McKinney ... as well as for those mentioned in my discussion of discrimination in the present case." In other words, the Court in this case explicitly analyzed the Section 15 violation of the right to equality and the Section 1 justification of this violation using the same considerations. ${ }^{41}$

To give another example, in the McKinney case-the aforementioned case of the application of professors against a mandatory retirement age, in which the Charter was determined not to applythe Court declined to use a similar rational connection test in its Section 15 analysis, rejecting an argument to that effect: "[I]t seems difficult to argue ... that [these policies] are not discriminatory ... since the distinction is based on the enumerated personal characteristic of age." Thus, the Court focused in that case on its-theoretical, since the Charter did not apply-Section 1 analysis and found the Section 15 violation was justified because of a rational connection between the measure and the objective and an impairment of the right, which was as little as possible. ${ }^{42}$

In practice, there have been only two exceptions in which the Court found a violation of Section 15 that was justified according to Section 1 -and not in a theoretical case, in which the Charter does not apply. In 2002, in Lavoie v. Canada, a case involving an application against the preferential treatment of Canadian nationals in public service employment, ${ }^{43}$ the Court ruled that there was a violation of Section 15 but that it was justified as a reasonable limit on equality according to Section 1 of the Charter. This was the ruling, despite the fact that proportionalitytype tests were applied in examining violations of Section 15-for example, lack of "a genuine relationship between the ground upon which the claim is based and the nature of the differential treatment"and even though Section 1 justifications were made in similar terms-for example, "rational connection" and "close relationship." Another exception was a case in 2004, which found justified for financial reasons-namely, a financial crisis of the Province's government-a few years' deferment of a "pay equity" measure in favor of female employees in the health sector. ${ }^{44}$ Yet, these

\footnotetext{
${ }^{38}$ Andrews v. Law Society of British Columbia, [1989] 1 S.C.R. 143 (Can.).

${ }^{39}$ McKinney, [1990] 3 S.C.R. 229.

${ }^{40}$ Weatherall v. Canada (Attorney General), [1993] 2 S.C.R. 872; Rodriguez v. British Columbia (Attorney General), [1993] 3 S.C.R. 519 (Can.).

${ }^{41}$ Egan v. Canada, [1995] 2 S.C.R. 513, 535-38, 540.

${ }^{42}$ McKinney, [1990] 3 S.C.R. 229, 278-79, 282-89.

${ }^{43}$ Lavoie v. Canada, 2002 SCC 23, [2002] 1 S.C.R. 769.

${ }^{44}$ Newfoundland (Treasury Board) v. N.A.P.E., 2004 SCC 66, [2004] 3 S.C.R. 381 (Can.).
} 
two exceptions prove the rule, and they have not been repeated since the Court revised the equality test in 2011. As wellarticulated by Peter Hogg:

In the great majority of cases, the new element of human dignity in s. 15 [since 1999] leaves no role for s.1. It is obviously hard to justify a law that imposes a disadvantage on the basis of a listed or analogous ground and also impairs human dignity. When the Court uses the "correspondence" factor to decide the issue of human dignity, it considers whether the purpose of the law is legitimate and the use of a listed or analogous ground to accomplish the purpose is reasonable. This inquiry is really a loose form of the inquiry into justification under s. 1 . It is not surprising that $\mathrm{s}$. 1 has become less important in equality cases since the human dignity element was introduced by the Court in $1999 .{ }^{45}$

\section{South Africa}

Equality is enshrined in the South African Constitution in Section 9 of Chapter 2:

1. Everyone is equal before the law and has the right to equal protection and benefit of the law.

2. Equality includes the full and equal enjoyment of all rights and freedoms. To promote the achievement of equality, legislative and other measures designed to protect or advance persons, or categories of persons, disadvantaged by unfair discrimination may be taken.

3. The state may not unfairly discriminate directly or indirectly against anyone on one or more grounds, including race, gender, sex, pregnancy, marital status, ethnic or social origin, colour, sexual orientation, age, disability, religion, conscience, belief, culture, language and birth.

4. No person may unfairly discriminate directly or indirectly against anyone on one or more grounds in terms of subsection (3). National legislation must be enacted to prevent or prohibit unfair discrimination.

5. Discrimination on one or more of the grounds listed in subsection (3) is unfair unless it is established that the discrimination is fair.

This right is limited by the South African general limitation clause in Section 36 of Chapter 2:

1. The rights in the Bill of Rights may be limited only in terms of law of general application to the extent that the limitation is reasonable and justifiable in an open and democratic society based on human dignity, equality and freedom, taking into account all relevant factors, including
a. the nature of the right;
b. the importance of the purpose of the limitation;
c. the nature and extent of the limitation;
d. the relation between the limitation and its purpose; and
e. less restrictive means to achieve the purpose.

2. Except as provided in subsection (1) or in any other provision of the Constitution, no law may limit any right entrenched in the Bill of Rights.

The right to equality in South Africa is subject to limitations that include proportionality analysis.

\footnotetext{
${ }^{45}$ HoGG, supra note 29 , at 1226.
} 
The Constitutional Court of South Africa has specified a fourstep test to examine whether a law infringes upon the right to equality. First, the Court examines the question of a rational connection between the difference prescribed by the state and a legitimate government purpose. Second, the Court asks if the differentiation is discrimination. The Constitutional Court ruled that differentiation is discrimination if it focuses on a specified ground in Section 9(3) of the Constitutionrace, gender, or sex-or if "the ground is based on attributes and characteristics which have the potential to impair the fundamental human dignity of persons as human beings or to affect them adversely in a comparably serious manner." Third, the Court asks if the discrimination is "unfair." It will be presumed unfair if the discrimination is based on one of the specified grounds; otherwise, it can be established as unfair based on "the impact of the discrimination on the complainant and others in his or her situation." In assessing this impact and the question of whether the discrimination is "unfair," the Court has determined that the focus should be on the protection against invasions that impair human dignity. These first three steps establish a violation of the right to equality. The violation could then be justified, in the fourth step, based on the limitation clause and its tests of proportionality. ${ }^{46}$

In practice, the Court has never accepted a justification based on proportionality of a violation of the right to equality. The Court either finds that the right to equality has not been infringed-in the first three steps_ - or holds the infringement unjustifiable —in the fourth step. ${ }^{47}$ The reason for this practice is in the definition of the right to equality. In pursuit of a substantive definition of the right to equality, ${ }^{48}$ the constitutional provisions made the definition of equality redundant with the proportionality limitations. It did so in three senses. First and foremost, the Constitution prohibits "unfair" discrimination, imbuing "unfairness" with the idea of human dignity. If presumed unfair, because it is on one of the specified grounds, then the state already goes the length of trying to justify it. If rejected, what is the point of trying to justify it again, based this time on proportionality analysis? Second, the first step in examining infringement of the right to equality is already a "rational connection" test, which is part of the proportionality analysis. Third, part of the second step in examining infringement of the right-defining "discrimination"-includes an impairment of dignity. How can a court accept a justification of "unfair" discrimination that impairs human dignity? As Richard Stacey writes:

The section 9 right to be protected against unfair discrimination ... import[s] a proportionality analysis into the first stage of the rights inquiry. Where discrimination is found be to fair ... there is no infringement of the right. However, the inquiry into fairness or arbitrariness relies on much of the same logical musculature as the inquiry into proportionality. Where discrimination is unfair ... it is difficult to see how the infringement could be justified as reasonable, justifiable or proportionate despite the initial finding of unfairness .... ${ }^{49}$

The point can aptly be demonstrated through one of the Court's most famous equality cases: National Coalition for Gay and Lesbian Equality \& Others v. Minister of Justice \& Others. ${ }^{50}$ In that case, the Court declared the constitutional invalidity of offenses banning homosexual sexual acts. Specifically illuminating is the similarity between the Court's methodology in examining the question of whether the discrimination of homosexuals is "unfair," and the methodology in

\footnotetext{
${ }^{46}$ Harksen v. Lane 1997 (11) BCLR 1489 (CC) (S. Afr.); Robinson v. Volks 2005 (5) BCLR 446 (CC) (S. Afr.).

${ }^{47}$ Richard Stacey, Rights Limitation and Transformative Constitutionalism: Proportionality Analysis in the Service of Constitutional Values, in Proportionality in ACtion: Comparative Perspectives on Proportionality ANalysis (Mordechai Kremnitzer et al. eds., forthcoming Apr. 2020).

${ }^{48}$ On the substantive meaning of the right to equality in South Africa, see SHADRACK B. O. GUTTO, EQUALITY AND NONDiscrimination in South Africa: The Political Economy of LaW and Law Making 128-30 (2001).

${ }^{49}$ Stacey, supra note 47.

${ }^{50}$ National Coalition for Gay \& Lesbian Equality \& Others v. Minister of Justice \& Others 1999 (1) SA 6 (CC); 1998 (12) BCLR 1517 (CC) (S. Afr.).
} 
examining the justification of it through proportionality. As to fairness, Justice Ackerman explained: "[T]he discrimination has, for the reasons already mentioned, gravely affected the rights and interests of gay men and deeply impaired their fundamental dignity." He added that the "above analysis confirms that the discrimination is unfair. There is nothing which can be placed in the other balance of the scale." 51 This "other balance of the scale," to which Justice Ackerman referred, is mentioned in another case, which he quotes, namely:

[T] he nature of the provision or power and the purpose sought to be achieved by it. If its purpose is manifestly not directed, in the first instance, at impairing the complainants in the manner indicated above, but is aimed at achieving a worthy and important societal goal, such as, for example, the furthering of equality for all. ${ }^{52}$

This type of methodology - a balancing of values or purposes-is distinctly close to proportionality analysis in the narrow sense-the third subtest of proportionality. As illustrated in Justice Ackerman's treatment of the proportionality analysis in this case:

The balancing of different interests must still take place. On the one hand there is the right infringed; its nature; its importance in an open and democratic society based on human dignity, equality and freedom; and the nature and extent of the limitation. On the other hand there is the importance of the purpose of the limitation .... The criminalisation of sodomy in private between consenting males is a severe limitation of a gay man's right to equality in relation to sexual orientation .... Against this must be considered whether the limitation has any purpose and, if so, its importance. No valid purpose has been suggested .... There is accordingly nothing, in the proportionality enquiry, to weigh against the extent of the limitation and its harmful impact on gays. ${ }^{53}$

The similarity of balancing in terms of the fairness of discrimination and in terms of proportionality analysis is very clear. This similarity makes proportionality analysis virtually redundant when used in tandem with fairness analysis. This redundancy explains the focus in South Africa on the first stage of judicial review — has the right to equality been infringed—rather than on the second stage of justifying the infringement.

\section{The European Court of Human Rights}

The right to non-discrimination is enshrined in Article 14 of the European Convention on Human Rights ("ECHR") and in Protocol 12. Non-discrimination could be protected by either the ECtHR, the court in Strasbourg established by the ECHR, or by the European Court of Justice ("ECJ"), the court of the European Union. ${ }^{54}$

Generally, the ECtHR uses a twostage review in examining violations of rights enshrined in the ECHR. First, has there been an "interference" with the right? Second, "a further examination is required to determine whether this meets the three standards established in case law," ${ }^{2}$ including that the interference is according to law or prescribed by law, for a legitimate purpose, and "necessary in a democratic society" - in other words, a limitation clause that includes proportionality. The ECtHR has consistently used the principle of proportionality in balancing the rights of

\footnotetext{
${ }^{51} I d$. at paras. $26-27$.

${ }^{52} \mathrm{Id}$. at para. 19.

${ }^{53} I d$. at paras. $35-37$.

${ }^{54}$ James D. Dinnage \& John F. Murphy, The Constitutional Law of the European Union 947-48 (2d ed. 2008).

${ }^{55}$ Yutaka Arai-Takahashi, The Margin of Appreciation Doctrine and the Principle of Proportionality in the JURISPRUDENCE OF THE ECHR 9 (2002).
} 
individuals versus the interests of society, ${ }^{56}$ although in some cases, it has used versions of absolute rights or cores of rights. ${ }^{57}$

In terms of non-discrimination, according to Article 14, the ECtHR uses proportionality-not to ask whether an interference to a right is justified, but to examine whether a differentiation infringes on the right to equality. ${ }^{58}$ The right to equality does not stand alone, but must be "parasitic" to another right. ${ }^{59}$ Thus, the ECtHR has defined discrimination, under Article 14 of the ECHR, as a difference in treatment in the exercise of another right-besides equality-between categories of persons without "an objective and reasonable justification." ${ }^{60}$ As summarized in the 1968 Belgian Linguistic case, in which Frenchspeaking parents applied against the lack of French language education in the Belgian municipalities in which they lived, considered by the Belgian government to be Dutchspeaking:

It is important, then, to look for the criteria which enable a determination to be made as to whether or not a given difference in treatment, concerning of course the exercise of one of the rights and freedoms set forth, contravenes Article 14 (art. 14). On this question the Court, following the principles which may be extracted from the legal practice of a large number of democratic States, holds that the principle of equality of treatment is violated if the distinction has no objective and reasonable justification. The existence of such a justification must be assessed in relation to the aim and effects of the measure under consideration, regard being had to the principles which normally prevail in democratic societies. A difference of treatment in the exercise of a right laid down in the Convention must not only pursue a legitimate aim: Article 14 (art. 14) is likewise violated when it is clearly established that there is no reasonable relationship of proportionality between the means employed and the aim sought to be realised. ${ }^{61}$

In other words, the justification for the difference of treatment is already within the definition of the scope of the right. The notion of discrimination, according to the ECHR, includes a restriction clause in the sense that only differentiations that are not justified are seen as discrimination. "[C] ase-law has made clear that not every distinction or difference of treatment amounts to discrimination ...." Discrimination only occurs if the action "has no objective and reasonable justification," meaning that it does not pursue a legitimate aim or if there is not a reasonable relationship of proportionality between the means and the aim. ${ }^{62}$ That is why Article 1 of Protocol 12 -which was meant to have the same meaning as Article 14 of the ECHR - did not include a restriction clause. "Since not every distinction or difference of treatment amounts to discrimination, and because of the general character of the principle of non-discrimination, it was not considered necessary or appropriate to include a restriction clause in the present Protocol." ${ }^{33}$ In this way, the right to equality is an absolute right, according to the ECtHR, because any justified differentiation is not seen as infringement of the right and, conversely, no infringement is allowed. ${ }^{64}$

\footnotetext{
${ }^{56}$ Id. at 14; Steven Greer, The European Convention on Human Rights: Achievements, Problems and Prospects 203, 217 (2006).

${ }^{57}$ GREER, supra note 56, at 209-11. Cf. Shlomit Stein, In Search of 'Red Lines' in the Jurisprudence of the ECtHR on Fair Trial Rights, 50 IsR. L. REV. 177-209 (2017).

${ }^{58}$ Luisa Conesa, The Tropicalization of Proportionality Balancing: The Colombian and Mexican Examples, Cornell Law School Inter-University Graduate Student Conference Papers, paper 13 (2008), https://scholarship.law.cornell.edu/lps_clacp/13/.

${ }^{59}$ Charilaos Nikolaidis, The Right to Equality in European Human Rights Law: The Quest for Substance in THE JURISPRUDENCE OF THE EUROPEAN COURTS 51-55 (2015). For some exceptions to this parasitic nature of the right to equality, see $i d$. at 59 .

${ }^{60}$ GREER, supra note 56 , at 221.

${ }^{61}$ Belgian Linguistic Case (No. 2), App. No. 2126/64, 1 Eur. H.R. Rep. 252 (1968).

${ }^{62}$ Alastair Mowbray, Cases and Materials on the European Convention on Human Rights 620 (2001).

${ }^{63} \mathrm{Id}$. at 621.

${ }^{64}$ NiKOLAIDIS, supra note 59 , at 55 .
} 
ECtHR case law first examines whether a distinction is found prima facie to violate Article 14 with regard to equal treatment. Such distinction is assumed a prima facie violation in need of proportionality examination when applicable to suspect categories-race, sex, or illegitimacy. ${ }^{65}$ Yet, there is a double standard, because in cases of nonsuspect categories, "the standard of proportionality may also be lowered." ${ }^{66}$ If it is thus found in violation, the court examines whether it is justified under the proportionality test of the European Charter of Human Rights: ${ }^{67}$

[A] difference of treatment is discriminatory if it has no objective and reasonable justification, that is, if it does not pursue a legitimate aim or if there is not a reasonable relationship of proportionality between the means employed and the aim sought to be realised. ${ }^{68}$

The justifications include mainly four factors: (1) Less favorable treatment compared to comparable groups, "determined objectively by the complaint itself"; (2) the state has to show that "the practice is reasonable and rational"; ${ }^{69}$ (3) disproportion between the effect of the treatment and the policy objective, and the effect failed to strike a just balance between rights and interests; and (4) is the practice regarded as discriminatory in other democratic states. ${ }^{70}$

In sum, the ECtHR usually pursues a twostep examination of an infringement of human rights, in which proportionality analysis is utilized in the second stage examining the justification of the infringement. Yet, with regard to the right to equality, ECtHR doctrine requires that proportionality is used differently, in a singlestage constitutional review, in order to examine whether an infringement occurred in the first place.

\section{Flexible Systems}

Germany and Israel manifest a different model of applying proportionality in cases of the right of equality: A sliding scale. In Germany, the courts explicitly prescribe the flexibility in doctrine. In Israel, flexibility is apparent in practice rather than prescribed by doctrine. In both cases, this inconsistency is a symptom of the problematic overlap of the doctrine of proportionality with the right to equality.

\section{Germany}

The right to equality is enshrined in Section 3 of the German Constitution:

1. All persons shall be equal before the law.

2. Men and women shall have equal rights. The state shall promote the actual implementation of equal rights for women and men and take steps to eliminate disadvantages that now exist.

3. No person shall be favoured or disfavoured because of sex, parentage, race, language, homeland and origin, faith, or religious or political opinions. No person shall be disfavoured because of disability.

Proportionality analysis is not enshrined in the German Constitution. Rather, the German Federal Constitutional Court ("FCC") developed the principle of proportionality in its constitutional doctrine. $^{71}$ Yet, it has not applied the doctrine similarly in all of the rights detailed in the

\footnotetext{
${ }^{65}$ GreER, supra note 56, at 222; ARAI-TAKAHASHI, supra note 55, at 169.

${ }^{66}$ ARAI-TAKAHASHI, supra note 55 , at $169,174-75$.

${ }^{67}$ ARAI-TAKAHASHI, supra note 55 , at 169 .

${ }^{68}$ Religionsgemeinschaft der Zeugen Jehovas v. Austria, App. No. 40825/98, (July 31, 2008), http://hudoc.echr.coe.int/eng? $\mathrm{i}=001-88022$.

${ }^{69}$ GreER, supra note 56, at 221.

${ }^{70}$ GREER, supra note 56 , at 222.

${ }^{71}$ BARAK, supra note 1 , at $179-80$; Sweet \& Mathews, supra note 1 , at 98-112.
} 
Constitution. Significantly, the Court's proportionality analysis doctrine - with regard to the right to equality - has been markedly different than its application of proportionality analysis with regard to other rights such as freedom and property rights. As explained by Judge Gertrude Lübbe-Wolff:

The basic question here is whether equal treatment rights should be construed as open to restrictions (rather than seeing justified differentiations - like those attached to specific vulnerabilities such as may result from pregnancy or youth - as not constituting unequal treatment at all). ${ }^{72}$

And so, the Court has not always used proportionality analysis. At times, it has simply applied an interdiction of arbitrariness, while at other times it has applied stricter standards, up to a strict proportionality test. In other words, "in cases involving legislative review, the equality doctrine has developed into a refined system of flexible multilevel tests," described as "a flexible system of sliding tests." ${ }^{\prime 3}$ Yet, "in which cases exactly a proportionality standard applies and what exactly it means in the context of the right to be treated equally is, however, unclear." ${ }^{\prime 4}$ As the Court explained in a 2010 decision-in which it ruled that an amendment to the Genetic Engineering Act was constitutional-in response to a claim that it discriminated against users of genetic engineering in comparison to other farmers:

The general principle of equality ... demands that all people be treated equally before the law. However, this does not prohibit the legislature from all discrimination. Depending on the area of regulation and the distinguishing elements, the legislature is confronted with different limits, reaching from the mere prohibition of arbitrariness to a strict requirement of proportionality. ${ }^{75}$

In that case, the Court only applied a standard of arbitrariness as limiting the legislature, because "the concern here is the different treatment of different factual situations." Thus, the court ruled that "the legislature based this discrimination on pragmatic criteria ... by discriminating along these lines, the legislature pursues the legitimate publicinterest aims set out above .... These are so important ... that they do also justify unequal treatment ..." ${ }^{76}$ In other words, the Court only applied a standard of relevance-or lack of arbitrariness - in order to justify the unequal treatment. Thus, despite using a language of "justification" of some violation of equality, in using a standard of relevance, it seems the court was in practice examining the actual violation of the right, because if the differential treatment is relevant as it relates to different factual circumstances, in Aristotelian terms, it is not really an unequal treatment. The Court also treated this issue similarly in ruling that the "Civil Partnerships Act violates neither the special prohibition of discrimination ... nor the general principle of equality" because of relevant differences between the types of couples. ${ }^{77}$ In other cases, the Court has used such a standard to rule that an act is unconstitutional. ${ }^{78}$

The distinction between the violation of right analysis and the justification of this violation is made clearer in another 2013 case, where the Court ruled that the unequal treatment of children and civil partners in a law was unconstitutional, because it denied one civil partner the right to adopt the adopted child of the other civil partner while permitting the adoption of an adopted

\footnotetext{
${ }^{72}$ Gertrude Lübbe-Wolff, The Principle of Proportionality in the Case-Law of the German Federal Constitutional Court, 34 Hum. RTS. L.J. 12, 13 (2014).

${ }^{73}$ Susanne Baer, Equality: The Jurisprudence of the German Constitutional Court, 5 Colum. J. Eur. L. 249, 258, 262 (1999).

${ }^{74}$ Lübbe-Wolff, supra note 72, at 13. See also PETERSEN, supra note 4, at 99.

${ }^{75}$ Bundesverfassungsgericht [BVerfG] [Federal Constitutional Court] Nov. 24, 2010, 1 BvF 2/05, para. 313.

${ }^{76} \mathrm{Id}$. at paras. $314-16$.

${ }^{77}$ Bundesverfassungsgericht [BVerfG] [Federal Constitutional Court] July 17, 2002, 1 BvF 1/01, paras. $104-08$.

${ }^{78} \mathrm{See}$, e.g., in a taxation context, Bundesverfassungsgericht [BVerfG] [Federal Constitutional Court] Mar. 9, 2004, 2 BvL 17/02.
} 
child of a spouse and the adoption of a biological child of a civil partner. In deciding the matter, the Court explained: "The general right to equality requires the legislature to treat matters that are essentially the same in the same manner and those matters that are essentially different in a different matter." In other words, enunciating the Aristotelian definition of the right to equality. The Court continued to explain that:

Depending on the subject of regulation and the characteristics used to differentiate, constraints imposed upon the legislature to justify unequal treatment vary, ranging from a relaxed standard that is limited to a prohibition of arbitrariness to a standard of strict proportionality .... A stricter standard may result, in particular, from the liberty rights affected. ${ }^{79}$

In that particular case, the Court applied a stricter standard of review than a prohibition of arbitrariness but refrained from applying proportionality: "The unequal treatment is not justified ... the difference between a registered civil partnership and a marriage is not of a quality that could justify unequal treatment with regard to successive adoption, the general exclusion of which may serve a legitimate purpose." The Court examined the considerations and their consistency with the objectives but did not call the analysis "proportionality," nor did it apply all of the regular subtests of proportionality. ${ }^{80}$

Therefore, two areas remain somewhat murky. First, is the focus of the Court on the violation of the right? The limits that the legislature is confronted with, either with regard to arbitrariness or to a strict requirement of proportionality, could be construed as relating to the issue of the violation of the right or the issue of justifying this violation. This answer has not been made entirely clear. Second, it is murky when each limit applies - from prohibition of arbitrariness to proportionality. At least at this point in time, the Court seems to prefer flexibility of standards, opting sometimes on lax standards focused on the violation of the right, while opting at other times on stricter standards focused on examining the justifications of such violations.

\section{Israel}

Israel also manifests the second model — an inconsistent or flexible application of the proportionality doctrine. As a matter of doctrine-at least in the constitutional review of legislation - the proportionality doctrine applies with regard to the right to equality just the same as in any other right. Yet, the doctrine is not, in fact, consistently applied in equality contexts. Indeed, in some cases, the courts tend to use a singlestage constitutional review essentially focusing on the first stage of the constitutional review. ${ }^{81}$ The Israeli case manifests an attempt to ignore the pathology of the problematic interaction between the doctrines of proportionality and equality. At least when reviewing the constitutionality of legislation, the courts attempt to apply proportionality-in contexts of the right to equality - the same as any other right. Yet, the pathology referred to above is still manifest in the courts' decisions, in their inconsistency, in constitutional review of such cases, and in administrative law.

The right to equality, or non-discrimination, is protected in several Israeli statutes, but it is not literally mentioned in the two basic laws in which, in 1992, Israel constitutionally enshrined a few human rights. Yet, since a few years after their enactment, the Israeli courts have partially read the right to equality into the right to human dignity- "There shall be no violation of the life, body or dignity of any person as such"-which is enshrined in Section 2 of the Basic Law: Human Dignity and Liberty. The Israeli courts recognized that some infringements of the right to equality also infringe the right to human dignity, and they see the Basic Law as protecting against such

\footnotetext{
${ }^{79}$ Bundesverfassungsgericht [BVerfG] [Federal Constitutional Court] Feb. 19, 2013, 1 BvL 1/11, para. 72.

${ }^{80} I$ d. at paras. $74-76$.

${ }^{81}$ Barak Medina \& Assur Weizman, The Constitutional Revolution or the Human Rights Revolution? On the Constitutional Basis of "Institutional" Norms, 40 Iyoney Mishpat 595 (Tel-Aviv Univ. L. Rev.) (2018).
} 
infringements. The Basic Law also includes, in Section 8, a limitation clause: "[T]here shall be no violation of rights under this Basic Law except by a law befitting the values of the State of Israel, enacted for a proper purpose, and to an extent no greater than is required." The Israeli courts have read the standard tests of the proportionality doctrine into this limitation clause, namely: (1) The violation is according to law or prescribed by law; (2) it is for a proper or legitimate purpose; (3) with a rational connection between the means and the ends; (4) the means are necessary without an alternative measure that may achieve the same end with a less onerous limitation of the right; and (5) a balancing of the benefits to the purpose of the measure and the detriments of the limitation of the right. ${ }^{82}$ The Israeli courts apply the doctrine of proportionality in a uniform manner with regard to all rights enshrined in the two basic laws enacted in 1992. The focus in Israel is to a large extent on proportionality analysis, as infringement of rights - not just the right to equalityis easily proven in court. ${ }^{83}$

The courts have expanded, through interpretation, the constitutional protection accorded to the right to equality in Israel in the past two decades. The first test applied to examine a government infringement of the administrative right to equality - as opposed to the constitutional right-also used before the legislation of the basic laws in 1992, was the Aristotelian test of relevant differences. The Aristotelian test particularly focused on the relevant "equality group"-for example, to whom one should be equal to. This test is still considered by the courts to be the main definition of the right to equality. Yet, since 1995, the courts in Israel have added a constitutional right to equality based on the right to human dignity. Because the right to equality is not actually mentioned in the Basic Law - rather, the courts have read it into the right to human dignity - the exact scope of this right is unclear. ${ }^{84}$

At first, the courts saw the constitutional right to equality as infringed upon in cases where the state differentiates between individuals based on their being part of a distinct social group, such as gender or race. The court explained at the time, in the case of Alice Miller-in which a woman argued successfully that Army policy to refrain from enlisting women as army pilots was unlawful - that such a differentiation humiliates because it treats women as an inferior group and thus violates their right to human dignity, which is protected by the Basic Law. ${ }^{85}$ Yet, for over a decade now, the courts in Israel have expanded the test used to examine whether the state differentiates between groups of people in a way that infringes human dignity in a "materially tight" manner. ${ }^{86}$ Such an infringement occurs, according to the Supreme Court, where the ability of a person to manage her own life is hurt; to act autonomously, to preserve her physical and mental integrity; to develop her personality; and to enjoy a non-discriminatory treatment. ${ }^{87}$ Thus, discrimination is possible not only based on the formerly narrow social grounds, such as race or gender, but also based on other less defined grounds. The courts' doctrine in Israel is not completely consistent, and both former tests - the narrower definition applied only to suspect groups and the Aristotelian test of relevant differences-are still used. ${ }^{88}$

Generally speaking, the doctrine of the court states that it follows, with regard to infringements of the right to equality, the same twostep proportionality doctrine in constitutional review of

\footnotetext{
${ }^{82}$ BARAK, supra note 1 , at 208-10.

${ }^{83}$ Barak Medina, Human Rights LaW in IsRael 273 (2016).

${ }^{84} \mathrm{Cf}$. Brandes, supra note 21.

${ }^{85} \mathrm{HCJ} 4541 / 94$ Miller v. Minister of Defence IsRLR 1 (1995) (Isr.).

${ }^{86} \mathrm{HCJ}$ 7052/03 Adalah, The Legal Center for Arab Minority Rights in Israel v. the Minister of the Interior, para. 39 of Chief Justice Aharon Barak's decision (2006).

${ }^{87} \mathrm{HCJ}$ 6427/02 The Movement for the Quality of Government v. The Knesset (2006) (Isr.).

${ }^{88}$ Aharon Barak, Human Dignity 696 (2014); Medina, supra note 83, at 285; Sigal Kugot \& Efrat Hakak, Has a Constitutional Right Been Infringed? The Need to Set Clear Limits to a Constitutional Right-The Right to Equality as an Example, 7 SHA'AREI MiSHPAT 99 (2004); HCJ 8300/02 Nasser v. The Government of Israel (2012).
} 
legislation. ${ }^{89}$ In numerous cases, the court has found an infringement of the right to equality in the first step, and then declared it justified according to proportionality analysis. A case in point involves a petition of a single woman against a law allowing only couples the benefit of a stateregulated process legalizing surrogate motherhood. The Supreme Court stated that the law discriminates against her. The Court saw the differentiation between single mothers and couples as irrelevant for the purposes of the law; it saw it as discrimination without justification. Yet, continued the Court, in light of the novelty of both the process and the attempt to regulate it, the law was nonetheless constitutional. The Court explicitly stated that even if the discrimination of single women infringed upon their right to equality and human dignity, such infringement was proportional. ${ }^{90}$ Some commentators have argued that affirmative action should be similarly analyzed, being seen as an infringement of the right to equality and then examined for its justification — and justified in certain cases-according to the proportionality doctrine. ${ }^{91}$

When the court applies proportionality, it sometimes tends to focus on the second step of the proportionality doctrine. Commentators in Israel have critically noted that the lack of clear definitions of the exact scope of the right to equality has been responsible for a lack of focus on the first step of the question of violation of the right. They have called for a clearer or more substantial definition of equality, which would give greater respect to the right to equality and to the legislature. ${ }^{92}$ Why has the court focused on the second stage of constitutional review when applying proportionality? There could be two reasons for this practice. First, the vague definition of the right to equality. This vague definition is due to the fact that the right to equality has not been mentioned in the Basic Law on which the Supreme Court bases its jurisprudence. Second, this courtbased development of the scope of the right has become wide and nonsubstantive. While connected to human dignity, the Supreme Court has explicitly rejected a narrow definition of this connection-linked to humiliation and the core of human dignity-and instead opted for a wide and diffuse definition of the scope of the right to equality. ${ }^{93}$ Such a definition lets the plaintiffs prove relatively easily that a state action violates their right to equality in the first stage of constitutional review, granting the court discretion to decide if this violation is justified in the second stage of constitutional review.

All of the above is true when the court applies proportionality to review legislative infringements of the right to equality. Nevertheless, the court has not been completely consistent with regard to the application of the right to equality and its definition. Often, it has not applied proportionality at all. Israeli courts' doctrine on the right to equality is notoriously inconsistent. In some cases, the courts justify violations of the constitutional right to equality with minimal or no mention of proportionality. In some cases, the courts use "relevant differences" tests, both in the administrative law right to equality and in the constitutional right, and in other cases they do not. In a few cases, the Supreme Court has implicitly, without actually saying so, used a onestep test, seeing a violation of the right to equality as categorically forbidden. ${ }^{94}$ These cases involved allocation of state funds to select groups of people based on irrelevant political considerations, such as in cases of tax benefits to particular towns and not to others, or state support of students from religious educational institutions and not of other students. ${ }^{95}$

\footnotetext{
${ }^{89} \mathrm{HCJ}$ 1877/14 The Movement for the Quality of Government v. The Knesset, paras. 41, 51-52 of Chief Justice Miriam Naor's decision (2017) (Isr.). Cf. HCJ 4541/94 Miller v. Minister of Defence IsRLR 1 (1995) (Isr.).

${ }^{90}$ HCJ 2458/01 New Family v. The Committee for the Approval of Fetus Carrying Agreements (2002) (Isr.).

${ }^{91}$ Suzie Navot \& Moran Kandelshtein-Haine, Affirmative Action as "Constitutional Discrimination", in ELIAHU MAZZA Book 145 (Aharon Barak et al. eds., 2015).

${ }^{92}$ Kugot \& Hakak, supra note 88. Cf. Barak Medina, The Right to Equality in the Supreme Court Case Law: Human Dignity, the Public Interest and Distributive Justice, 17 Mishpat U'Mimshal 63 (2016).

${ }^{93} \mathrm{Cf}$. Brandes, supra note 21.

${ }^{94}$ Medina \& Weizman, supra note 81 .

${ }^{95}$ Medina \& Weizman, supra note 81 .
} 
In sum, as a matter of doctrine, Israeli courts say that the proportionality doctrine applies in cases of claimed violations of the right to equality, just as it applies in the context of other rights. The problems of application in Israel are manifest in the inconsistent application of proportionality in right to equality contexts, and especially in the tendency to sometimes use a singlestage constitutional review.

\section{E. Discussion}

To summarize, in the first model, courts practice constitutional review differently in the context of the right to equality than in the context of other rights. The courts in the first model discard the twostep constitutional review. Rather, they apply a singlestep constitutional review, focused on defining the scope of the right and its infringement. The proportionality tests are essentially submerged in the first stage of the constitutional review and are used-if at all—to define the scope of the right and see if it had been infringed, rather than to question the justification of the infringement in some optimization of principles. In Canada and South Africa, the courts essentially use tests that make proportionality analysis redundant because of their similarity to its three subtests: Rational connection between means and ends, the means are necessary, and a balancing of benefits and detriments. In such a model, the prohibition against discrimination acts more like a categorical prohibition, a deontological rule rather than a principle. In the second model, courts basically apply proportionality in an inconsistent manner, either explicitly as part of a flexible doctrine - in Germany — or implicitly as a matter of practice - in Israel. Either way, inconsistency or flexibility is a manifestation of the problematic overlap of the doctrine of proportionality with the right to equality.

What is the significance of the choice of one model over another? Returning to the criticisms to or the disadvantages of proportionality, the first model mitigates many of them. In such a model, the courts show more respect to the concept of human rights. The courts examine the scope of the right to equality in detail, and if they deem it infringed, they, in essence, view the right in categorical deontological terms. It is, in a way, strictly prohibited to discriminate in the first model; one cannot in practice justify such a violation of the right to equality, once the court determines that it was infringed. ${ }^{96}$ Such a model treats equality as a trump or a firewall, rather than a principle to be optimized. The first model has the advantage over the second model in terms of the criticism that proportionality deflates the idea of human rights. ${ }^{97}$

The main empirical observation of this Article-namely pointing out the problematic application of the doctrine of proportionality in cases of infringement of the right to equality-supports one of the criticisms directed at the doctrine. Despite the purported "one size fits all" analysis of proportionality, this Article suggests that this doctrine is indeed difficult to apply consistently and universally, at least with regard to the right to equality.

Is this legal inconsistency problematic? Is the second model surveyed here better than the first model, in which proportionality is not applied in a way consistent in its application with other rights? That is not necessarily the case. We tend to admire legal consistency as it promotes certainty in parties applying to the court and legitimizes court decisions. Yet, if the doctrine of proportionality varies in application among rights, that in itself is not problematic in terms of the promotion of certainty and clarity, as long as the doctrine is explicitly and clearly stated in such terms. The problem in terms of certainty is perhaps greater when the doctrine itself is unclear or flexible - as in the second model surveyed here - or if its application in fact differs from its normative explication-as in Canada and South Africa.

Moreover, the fact that some subtests of proportionality are in practice used to define the right to equality may itself be significant. The usage of these tests outside the regular twostep doctrine of

\footnotetext{
${ }^{96} \mathrm{Cf}$. Fredman, supra note 18; O'Connell, supra note 18.

${ }^{97}$ See supra Section C.
} 
proportionality may attest to an inherent benefit imbued in them for the analysis of the legitimacy of state action. This view, rather than supporting the arguments of opponents of proportionality, actually buttresses the proponents of proportionality as a manifestation of the rule of law.

A question that remains unanswered in this Article is: Which model better protects against discrimination? Does the first model grant less protection to the right to equality? Is it the other way around, as the efficacy of the courts' protection is better that way? This question remains open to discussion, as it relates to the wider debate on the efficacy of the doctrine of proportionality in its protection of human rights in general, and to the issue of the substantive definition of the right to equality and whether it affords better protection against discrimination. In essence, one's position for or against proportionality would relate to where one stands in the choice of one of the models. If one accepts the criticisms directed at the doctrine of proportionality, then clearly the first model would seem superior to the second model. If one rejects these criticisms, then the second model may be deemed equal to the other or better. Similarly, one's position with regard to the substantive definition of the right to equality determines where one would stand on these issues. Supporters of a thick, substantive definition of equality would perhaps support the first model. In this context, and in terms of the relations among the Judiciary, the Executive, and the Legislature, perhaps a tradeoff of sorts occurs in the choice of the first model over the second. A thicker and more substantive definition of equality in the first model may perhaps result in a higher hurdle for petitioners to prove that their right has been infringed by the state. This practice may be interpreted as the court's deference toward the political branches, yet once proven, that ends discussion. The court does not allow any type of justification, but rather absolutely protects the right to equality. The first model could be perceived in this light as a stronger protection of equality with less deference to the political branches. Indeed, in this light, the first model respects the right to equality more than the second model does. Thus, in educational terms and in terms of providing guidance to authorities, the first model could have the advantage over the second model. Lastly, the tendency of some courts to adopt the first model, despite the language of their jurisdictions' constitutions, could also lend support to the case of the advocates for the protection of human rights under the understanding of them as absolutely protected.

\section{F. Conclusion}

This Article focused on the overlap and interaction between the doctrine of proportionality and the right to equality. Proportionality and the tests applied to examine a claimed violation of the right to equality do not work well together. Both doctrines are relational normative measures between the ends and the means of state policies and, as such, their overlap and interaction are problematic. The various tests used by courts to examine when differential treatment amounts to discrimination are not easily compatible with the regular twostep constitutional review according to the doctrine of proportionality. Tests involving suspect grounds for discrimination are problematic because they often act as a categorical prohibition. Thus, even if proportionality is applied in such cases to non-discrimination, courts tend to utilize it as a rule rather than as analytical tool to optimize principles. When suspect grounds are not involved in tests for discrimination, any definition of the right to equality involves relational measures that make the uses of the tests of proportionality redundant or cumbersome. Indeed, when trying to imbue some substantive quality to the right to equality, jurisdictions often resort to tests that sound very close to proportionality or are otherwise a relational meansends test or measure, much like proportionality.

The Article has three main contributions to the comparative constitutional literature. First, the courts of Canada, Germany, Israel, and South Africa, as well as the European Court of Human Rights, face the same pathology in trying to apply the doctrines of proportionality and the right to equality.

Second, this Article surveyed the two models that courts use in applying proportionality in the context of the violation of the right to equality: (1) A doctrine or practice of constitutional review 
focusing on the scope of the right and its infringement; and (2) a sliding, or inconsistent, scale. The courts in the first model-Canada, South Africa, and the ECtHR - discard the twostep constitutional review usually done in proportionality doctrine, and apply instead a singlestep constitutional review, focused on defining the scope of the right and its infringement. In their singlestep review, the courts of Canada and South Africa use tests that make proportionality analysis redundant, because of their similarity to its three subtests. The courts of Israel and Germany utilize the second model - they basically apply proportionality in an inconsistent manner, either explicitly as part of a flexible doctrine, in the case of Germany, or implicitly as a matter of practice, in the case of Israel. In both cases, their inconsistency or flexibility is another manifestation of the problematic overlap of the doctrine of proportionality with the right to equality.

Third, the Article contributes to the ongoing discourse on the merits of the doctrine of proportionality. There are advantages and disadvantages to each choice of models. The choice of the model used by each court is relevant to the ongoing discourse on the advantages and disadvantages of the use of proportionality and, to some extent, such choice depends on one's position in this debate. On the one hand, the empirical findings of the Article, namely the problematic overlap between proportionality and the right to equality, suggest that some of the criticisms directed at the doctrine of proportionality are justified. Despite the claimed "one size fits all" analysis of proportionality, the doctrine is indeed difficult to apply consistently and universally, at least with regard to the right to equality.

On the other hand, the flourishing of these two models of accommodation to the problem shows that solutions exist. Proportionality does not have to work exactly the same with regard to every right. Indeed, perhaps the utilization of some of the tests of proportionality within the right to equality point to an inherent intuitive value in sifting illegitimate and legitimate state actions. Perhaps these tests have some inherent rational utility. One may argue that this utilization of these norms shows that a rational connection between the means and the ends of state actions, their necessity, and greater benefits to their purpose than detriment to rights are somehow indeed part of the basic idea of the rule of law, as argued by proponents of proportionality.

Cite this article: Lurie G (2020). Proportionality and the Right to Equality. German Law Journal 21, 174-196. https://doi.org/ $10.1017 /$ glj.2020.8 